Review

\title{
Current Insights into Migratory Endoparasitism: Deciphering the Biology, Parasitism Mechanisms, and Management Strategies of Key Migratory Endoparasitic Phytonematodes
}

\author{
Reny Mathew and Charles H. Opperman * \\ Department of Entomology and Plant Pathology, North Carolina State University, Raleigh, NC 27695, USA; \\ rmathew2@ncsu.edu \\ * Correspondence: warthog@ncsu.edu
}

Received: 1 May 2020; Accepted: 22 May 2020; Published: 26 May 2020

check for updates

\begin{abstract}
Despite their physiological differences, sedentary and migratory plant-parasitic nematodes (PPNs) share several commonalities. Functional characterization studies of key effectors and their targets identified in sedentary phytonematodes are broadly applied to migratory PPNs, generalizing parasitism mechanisms existing in distinct lifestyles. Despite their economic significance, host-pathogen interaction studies of migratory endoparasitic nematodes are limited; they have received little attention when compared to their sedentary counterparts. Because several migratory PPNs form disease complexes with other plant-pathogens, it is important to understand multiple factors regulating their feeding behavior and lifecycle. Here, we provide current insights into the biology, parasitism mechanism, and management strategies of the four-key migratory endoparasitic PPN genera, namely Pratylenchus, Radopholus, Ditylenchus, and Bursaphelenchus. Although this review focuses on these four genera, many facets of feeding mechanisms and management are common across all migratory PPNs and hence can be applied across a broad genera of migratory phytonematodes.
\end{abstract}

Keywords: migratory nematodes; Radopholus; Pratylenchus; Ditylenchus; Bursaphelenchus; plant-parasitic nematodes; parasitism genes

\section{Introduction}

Of approximately 27,000 described nematode species, roughly 4100 utilize higher terrestrial plants as a predominant source of nutrition [1]. These plant-parasitic nematodes (PPNs), cause $\sim \$ 80-\$ 157$ billion crop losses annually worldwide [2,3]. The earliest evidence of a nematode identified within a plant is the fossilized eggs, juveniles, and adults of Palaeonema phyticum (Poinar, Kerp, and Hass, 2008) in the stem of the terrestrial plant Aglaophyton major (Kidson and Lang, 1920) in the Devonian era [4]. This discovery of P. phyticum uncovered an ancient and a pivotal point in the timeline of transition of nematodes from free-living to parasites of land plants. Since microbes were found in the stomatal spaces invaded by the nematode, P. phyticum was tentatively categorized as a facultative plant-parasite, belonging to clade 1 of the phylum Nematoda (due to the morphological similarities to clade 1 nematodes) [4-6]. Feeding on fungi or bacteria or other microbes is also considered to be one of the most important determinants for the evolution of facultative or obligate plant-parasitism in nematodes. This evolution is thought to have occurred independently four times within Nematoda $[4,5,7,8]$. In the phylogenetic tree outlined by Van Megen et al., these events place PPNs in four of the twelve clades: 1 (Triplonchida), 2 (Dorylaimida), 10 (Aphelenchoididae), and 12 (Tylenchida). A prominent morphologically distinctive feature of all PPNs is a protrusible needle-like apparatus known as the stylet. The stylet, an artifact of convergent evolution (within 
the above-mentioned four clades) is utilized by PPNs for two main reasons: (1) puncturing the plant cell wall to extract cell nutrients, and (2) in certain nematode species, delivering secretory molecules into the apoplast and/or cytoplasm to manipulate host cells to develop a permanent feeding site $[9,10]$. Feeding mechanisms differ among PPNs; they are, therefore, a useful tool to group PPN species. Broadly speaking, PPNs are divided into two main categories based on feeding mechanism: endoparasitic and ectoparasitic. Ectoparasitic nematodes occupy clades 1 (Trichodoridae) and 2 (Longidoridae) in the Nematoda lineage; they feed on cortical root cells from outside the root. Clade 2 ectoparasitic nematodes of the genera Xiphinema and Longidorus utilize an odontostyle (as opposed to the stomatostylet, a feature common to clades 10 and 12 or onchiostyle in clade 1 PPN) to induce cell enlargement. Although the feeding apparatus used by Xiphinema and Longidorus is the same, the terminal plant cell feeding sites formed after this intimate biotrophic association are slightly different, with those formed by Xiphinema inducing plant cell karyokinesis and those formed by Longidorus remaining mononucleate [5]. In contrast to ectoparasitic nematodes, endoparasitic nematodes penetrate and feed within plant roots and have been a tremendous burden on global agricultural production, especially in developing areas like Sub-Saharan Africa, where the resources to diagnose and combat them are limited [11]. Endoparasitic nematodes can be further divided into two sub-categories: migratory and sedentary. Sedentary endoparasitic nematodes, such as the root-knot and the cyst nematodes, form specialized feeding sites, which act as nutritional sinks for the developing nematode. Migratory endoparasitic nematodes such as Scutellonema bradys (Steiner and LeHew, 1933) Andrassy, 1958, are a tremendous agricultural and economic burden on yam (Dioscorea spp.), a crop that has been a major source of income and an important part of the diet in the western regions of Africa [12,13]. A massive amount of genomic and transcriptomic information has been obtained about many migratory endoparasitic nematodes primarily through application of next-generation sequencing (NGS) technologies [14-20]. Analysis of this information has opened a novel gateway for researchers worldwide to formulate evidence-based conclusions regarding the biology, phylogenetic relationships, and parasitism mechanisms of these nematodes. In this review, we focus only on some of the economically important migratory endoparasitic PPNs from clades 10 and 12. For in-depth analysis of the effectors and processes targeted by sedentary endoparasites of clade 12, the authors suggest several other reviews [10,21,22].

\section{The Biology of Migratory Endoparasitic Nematodes}

A survey of PPN researchers worldwide ranked the top 10 economically significant and scientifically relevant PPNs [23]. Not surprisingly, migratory endoparasitic nematodes, such as root lesion nematodes (Pratylenchus spp.), burrowing nematode (Radopholus similis (Cobb, 1893) Thorne, 1949), stem or stem and bulb nematode (Ditylenchus dipsaci (Kuhn, 1857) Filipjev, 1936) and pine wood nematode (Bursaphelenchus xylophilus (Steiner and Buhrer, 1934) Nickle, 1970) occupy positions 3 to 6 in this list, following sedentary root-knot (Meloidogyne spp.) and cyst (Heterodera and Globodera spp.) nematode species [23]. With the exception of B. xylophilus, in clade 10, both migratory and sedentary endoparasitic nematodes are clustered together in clade 12 , indicating the possibility that the evolution of B. xylophilus into a plant parasite is a recent and convergent one [23]. B. xylophilus is also an exception when compared to the other migratory nematodes in the top ten list, in that, it is vectored by insects—specifically adult Monochamus (Cerambycidae) beetles (principal vectors), ovipositing on host pine trees [24]. B. xylophilus is a facultative plant-parasite, as it feeds on fungi (fungal mycelial mats) as well as xylem parenchyma of live trees. This feature is unique to Bursaphelenchus when compared to species of Pratylenchus, Ditylenchus, and Radopholus and most plant-parasitic nematodes, as they are obligate plant-parasites. However, in yet another exception, a newly discovered species of Bursaphelenchus named B. sycophilus, does not grow on fungal mycelial mats of Botrytis cinerea Pers or possess morphological characteristics like the fungal feeding species in this genus, making this nematode an obligate plant-parasite [25]. 
In the migratory endoparasitic nematodes, the genus Pratylenchus, which comprises of $\sim 70$ species, ranks third after sedentary root-knot and cyst nematodes, as an economically devastating pest of numerous agriculturally important crops and fruits [26]. An important feature that aids this pathogen in colonizing such a broad host range is the ability for different species to thrive in tropical and temperate climactic conditions. On the contrary, the other three migratory endoparasitic nematode genera, namely $R$. similis (distributed in tropical and temperate greenhouse conditions), D. dipsaci (worldwide specifically temperate regions), and B. xylophilus (the northern hemisphere, which is home to its vector, Monochamus beetles) have a comparatively narrower geographic distribution [27]. Different survival strategies are employed by these nematodes to survive or overcome harsh climactic conditions. For instance, $D$. dipsaci has been shown to survive for more than 20 years by entering into long-term anhydrobiosis [28]. Another migratory PPN, B. xylophilus, has been shown to overwinter in both living and dead tissues of coniferous trees, allowing it to endure long, harsh winters [29]. However, the molecular mechanisms underpinning cold tolerance in PPNs are multipartite and poorly understood at present [30]. Homologs of dauer genes have also been found in the genomic and transcriptome analysis of the burrowing nematode $R$. similis; however, since $R$. similis has not been shown to form dauers, the roles of these genes remain unclear $[14,19]$. There exist six distinct stages: eggs, four juvenile stages (J1-J4), and adults (female and rarely male) in the typical lifecycle of a PPN. The first molt, J1, occurs in the egg. Following this, hatching of the infective juvenile stage, J2, takes place. In most migratory endoparasitic nematodes, all stages (J2-J4 and adult females) possess the ability to infect host cells. Reproductive strategies employed by the different migratory endoparasitic nematode species described above are also oddly similar. Most of the species are dioecious; however, in the absence of males, alternate strategies are pursued, such as hermaphroditism in case of $R$. similis and parthenogenesis in case of certain lesion nematodes [23].

\section{Feeding Strategies Employed by Migratory Endoparasitic Nematodes}

Sedentary endoparasitic PPNs form multinucleate hypertrophied, permanent feeding sites, referred to as syncytium for cyst nematodes and giant cells for root-knot nematodes, which serve as a source of nutrition for the nematode. In contrast, for the migratory endoparasitic nematodes, the feeding mechanisms are fairly straightforward and comparatively less complex. Of these, the penetration and feeding mechanisms of the root-lesion nematode P. penetrans (Cobb, 1917) Filipjev and Schuurmans-Stekhoven, 1941, have been extensively studied [31-35]. Pratylenchus penetrans has been shown to feed ectoparasitically and endoparasitically [36]. Its endoparasitic feeding behavior can be classified into three distinct stages, namely root surface probing, root penetration, and infection. In the first stage, nematodes migrate primarily to the root hair region and sometimes closer the root tip, around the zone of elongation [33]. Once there, they ectoparasitically probe local epidermal cells and initiate stylet thrusting at an intensity probably proportional to the cell wall structure and thickness [35]. In the second stage, penetration, the regions next to the root intercellular walls are punctured with the stylet accompanied by a slight pressure from the labial region to allow the nematode to enter and create a gateway for subsequent nematodes to enter the root. Intense stylet thrusting continues during this stage as well. Following penetration and entry, the third stage, infection, is initiated. This stage is divided into two sub-stages, brief and extensive feeding. At the beginning of brief feeding, a small salivation zone is present surrounding the stylet tip when inserted into a host cell. The period of brief feeding differs between different nematode developmental stages with juvenile stages consuming less time (approximately 5 minutes) and the adult stages consuming more (approximately 10 minutes). Cortical cell response to the nematode's brief feeding period includes cytoplasmic streaming and rarely cell death, but nematode migration following these brief feeding periods induces cell death along the migration path. Additionally, preferential feeding behavior is also seen, with $\mathrm{J} 2$ and J3 life stages feeding on the root hair and the higher developmental stages (J4 and adults) feeding on the cortical cells [37]. During extended feeding periods, a relatively prominent salivation zone is formed, following 
which several cell-wall modifying enzymes (CWME) and effectors are secreted into the host cell prior to ingestions.

Over many years, numerous CWMEs, such as cellulases, pectate lyases, xylanases and arabinases, have been discovered in migratory and sedentary endoparasitic phytonematodes [38-43]. Of these, cellulases have been of particular interest to understand the underlying mechanism of host-parasitism and the role of horizontal gene transfer in the origin of parasitism in phytonematodes. Cellulases breakdown cellulose, the major structural component of plant cell walls. Cellulases of root-knot and cyst nematodes have been extensively studied since they are involved in the preliminary interaction with host tissues. The cellulases secreted by sedentary endoparasitic nematodes during the mechanical root puncturing and migration activity have been shown to be homologous to bacterial cellulases, suggesting a possible ancient horizontal gene transfer (HGT) event between bacteria and nematodes with plant parasitism. Molecular characterization studies have confirmed the presence of four cellulases belonging to the GHF5 family (mainly bacterial cellulases) in the burrowing nematode, $R$. similis [39]. Of these, three showed relatively lower expression in males, most likely since males are non-feeding. In another migratory phytonematode, B. xylophilus, three cellulases belonging to the GHF45 family have been discovered [41]. GHF45 cellulases are secreted by many microbes including bacteria and fungi as well as some animals; however, the B. xylophilus cellulases have been shown to be of fungal origin as opposed to bacterial origin (and B. xylophilus feeds upon and lives in close association with fungi). In-situ hybridization studies have confirmed the expression of nematode cellulases specifically within the esophageal gland secretory cells of these parasites, corroborating the hypothesis that these proteins are secreted during the initial phases of parasitism (penetration and migration). However, parasitism proteins involved in disparate stages of host interaction can also be released by other tissues such as the amphids and hypodermis [10]. Cellulases have also been characterized in the molecular and transcriptomic studies of the lesion nematode P. penetrans, P. thornei (Sher and Allen), P. vulnus (Allen and Jensen, 1951), and P. zeae Graham, 1951 [15,16,37,44,45]. The P. penetrans GHF5 cellulases have shown similarity to those in cyst and root-knot nematodes, enforcing a previous finding that some of the early members of the Pratylenchidae family could be gene donors to the root-knot and cyst nematodes $[16,43]$. Additionally, due to their expression in all migratory endoparasitic nematode life stages, cellulases, specifically $\beta-1,4-$ endoglucanases, have been utilized to design diagnostic PCR markers for classification of different Pratylenchus species from soil and root samples [46].

In addition to cellulases, another secretory protein group extensively studied in PPNs are pectate lyases. Pectate lyases are involved in the breakdown of pectin, an essential component of the plant cell-wall involved in supporting the cellulose and hemicellulose fiber molecules within and between plant cell-walls [47]. Pectate lyases, specifically PL3, have been cloned and reported in numerous sedentary endoparasitic nematodes such as Meloidogyne, Globodera, and Heterodera [48-52]. In migratory phytonematodes, PL3 has been discovered in the genomes and transcriptomes of R. similis [14], P. coffeae (Campos and Villain, 2005), P. penetrans [16,17], D. destructor Thorne, 1945 [53], and B. xylophilus [40]. These PL3s are involved in softening the plant cell wall, thereby allowing the nematode to migrate through the intercellular spaces. In sedentary endoparasitic nematodes, close homologs of these pectate lyases secreted from the subventral esophageal glands have been shown to be of a bacterial and fungal origin [54]. Furthermore, RNAi knockdown studies of these pectate lyases in the sedentary endoparasitic phytonematode, $H$. schachtii Schmidt, 1871, culminated in fewer nematodes per root tissue sample of Arabidopsis thaliana (L.) Heynhold, 1976 plants, implicating the need for these enzymes in parasitism [55]. CWMEs such as arabinases, xylanases, and polygalactouranases have also been found during genomic and transcriptomic analyses of multiple parasitic phytonematodes $[2,38,47,56]$. However, extensive molecular characterization studies elucidating the interplay between different CWMEs during parasitism in migratory PPNs have not been performed, thereby leaving a significant gap in the knowledge necessary to understand the processes taking place during the course of infection by a migratory PPN. 


\section{Parasitism Gene Repertoire and Effectors of Migratory Endoparasitic Nematodes}

Low-cost and resource-efficient NGS technologies have opened gateways for researchers to analyze the arsenal of putative effectors secreted by PPNs. The broad definition of effectors proposed by Hogenhout et al., "all pathogen proteins and small molecules that alter host-cell structure and function", encompasses the spectrum of effectors secreted by PPNs [57]. PPN effectors are generally expressed and secreted by esophageal gland cells, specifically one dorsal and two subventral esophageal gland cells, through the stylet. The role of these esophageal gland cells in sedentary endoparasitic PPN is generally regulated; the subventral gland cells are metabolically active during the pre-parasitic and early infective stages, and the dorsal gland cells are active during a more permanent association with the host tissues [10,37]. An overview of some of the key parasitism genes discovered in economically important migratory PPNs since 2013 is provided in Table 1.

Table 1. List of some of the significant parasitism genes in the four key migratory plant-parasitic nematode (PPN) genera published since 2013.

\begin{tabular}{|c|c|c|c|}
\hline Gene Name/Cluster ID & Species & Function/Annotation & Reference \\
\hline \multicolumn{4}{|c|}{ Pratylenchus spp. } \\
\hline Ppen12895_c0_seq1 (FAR) & P. penetrans & Fatty-acid metabolism & [45] \\
\hline $\begin{array}{l}\text { Ppen12103_c0_seq1 } \\
\text { (SXP-RAL2) }\end{array}$ & P. penetrans & Function in parasitism: unclear & [45] \\
\hline Vap-1 & P. zeae & Host defense suppression & [15] \\
\hline Sec-2 & P. zeae & Overcoming host defense & [15] \\
\hline \multicolumn{4}{|c|}{ Radopholus similis } \\
\hline Rs-scp-1 & R. similis & $\begin{array}{l}\text { Development, invasion, and } \\
\text { pathogenesis in some PPN }\end{array}$ & [58] \\
\hline Rs-cps & R. similis & $\begin{array}{l}\text { Embryonic development invasion and } \\
\text { pathogenesis }\end{array}$ & [59] \\
\hline$R s-c b-1$ & R. similis & Reproduction and invasion & [60] \\
\hline Rs-crt & R. similis & Reproduction and pathogenicity & [61] \\
\hline Rs-far-1 & R. similis & $\begin{array}{l}\text { Development, reproduction, infection, } \\
\text { and disruption of plant defense }\end{array}$ & [62] \\
\hline \multicolumn{4}{|c|}{ Ditylenchus spp. } \\
\hline DD03093(VAP-1) & D. destructor & Host defense suppression & [63] \\
\hline DDC03397(VAP-2) & D. destructor & Host defense suppression & [63] \\
\hline DD03835 (Sec-2) & D. destructor & Overcome host defense & {$[63]$} \\
\hline \multicolumn{4}{|c|}{ Bursaphelenchus spp. } \\
\hline BxSapB1 & B. xylophilus & Contributes to virulence and cell death & [64] \\
\hline 1-3-endoglucanase & B. xylophilus & Cell-wall degrading enzymes & {$[65]$} \\
\hline Expansin-like protein & B. xylophilus & Cell-wall degrading enzymes & [65] \\
\hline Peroxiredoxin & B. xylophilus & Detoxifying enzyme & {$[65]$} \\
\hline Cytochrome-P450 & B. xylophilus & Detoxifying enzyme & {$[66]$} \\
\hline Glutathione-S-transferase & B. xylophilus & Detoxifying enzyme & {$[66]$} \\
\hline
\end{tabular}

\subsection{Pratylenchus spp.}

In P. penetrans, numerous effectors have been identified and their putative role in parasitism has been deciphered $[16,45]$. Some of the significant effectors discovered in the P. penetrans transcriptome include catalases (with $\mathrm{N}$-terminal signal peptide) and glutathione peroxidase that play role in shielding 
the nematode against host induced reactive oxygen species (ROS) molecules. Moreover, notable effectors identified in the transcriptome dataset include the venom allergen-like proteins (VAPs) that have also been identified in B. xylophilus and have been hypothesized to be involved in movement within the host plant [67]. Furthermore, effectors such as transthyretin-like proteins (TTLs) and fatty-acid and retinol-binding proteins (FARs) were also identified in the P. penetrans transcriptome dataset [45]. TTLs have been implicated to play an important role in the nervous system of $R$. similis and FARs from the cyst, and root-knot nematodes have been shown to bind precursor molecules involved in the defense related jasmonic acid signaling pathway [68-70]. During the comparative studies of root-lesion nematodes, several genes coding for PPN effectors involved in initiating a feeding site in host tissues were noted to be absent [15-17].

Transcriptome analysis of another member of this genus, P. coffeae, revealed several proteins homologous to effectors involved in parasitism [17]. Notable amongst them are the genes coding for chorismate mutase, glutathione peroxidase, glutathione-S-transferase peroxiredoxin, TTLs, and VAPs. A noteworthy finding of this study was the identification of proteins homologous to RBP-1, a cyst nematode secretory protein with an SP1a and ryanodine receptor domain (SPRYSEC). SPRYSECs have been shown to both suppress and elicit immune response in plants and within PPNs; these proteins have been identified only in the sedentary cyst nematodes [71]. The authors identified four putative SPRYSEC proteins in P. coffeae with a significantly high homology to the cyst nematode SPRYSECs [17]. In addition, the authors identified other SPRY domain containing proteins in P. coffeae as well. However, these do not show any similarity with the cyst nematode SPRYSEC proteins. A putative gene coding for an arabinogalactan galactosidase, a protein found only in the cyst nematodes, was also identified in $P$. coffeae. Additionally, many genes involved in cell-wall modification, such as $\beta$-1,4-endo-glucanase, pectate lyase, xylanase, and GH16 ( $\beta$-1,3-endoglucanases), were uncovered during the transcriptome analysis of P. coffeae [17]. However, no GH16s were identified in the transcriptome of P. penetrans, indicating the evolution of a distinct effector set in P. penetrans as a result of host/niche specialization [16].

Transcriptome analysis of another root-lesion nematode, P. zeae, an important pest of high-value crops such as sugarcane (Saccharum officinarum L.) and sorghum (Sorghum bicolor (L.) Moench), also revealed a similar trend in CWME occurrence [15]. Pratylenchus zeae possesses a similar suite of effectors when compared with close relatives, P. penetrans and P. coffeae. Notable in the transcriptome were the genes involved in combating host-derived oxidative stresses, such as glutathione S-transferase, peroxiredoxin, thioredoxin, glutathione peroxidase, and superoxide dismutase [15]. Additionally, genes identified in the transcriptome dataset of $P$. coffeae such as the cyst nematode secreted SPRYSEC proteins were also identified in $P$. zeae. Analysis of the putative secretome of $P$. zeae revealed several sequences involved in a variety of functions such as stress response, energy metabolism, protein digestion, host defense evasion, and plant cell wall modification [15]. Notably, the authors found expression of a gene with a SPRY domain localized within the nematode esophageal gland cells, implicating it in the parasitism process. The authors also noted that several genes involved in feeding site formation induced by sedentary nematodes such as C-terminally encoded peptides (CEP), CLE-like peptides, 16D10, and 7E12 were missing from the transcriptome analysis of P. zeae. Another important absence is of a gene coding for a putative chorismate mutase in $P$. zeae, which is present in the transcriptomes of P. coffeae and P. thornei.

\subsection{Radopholus similis}

Of the 30 described species of Radopholus, $R$. similis is the only major burrowing nematode species considered significant worldwide [72,73]. The transcriptome of $R$. similis has been sequenced twice [14,18]. Genes identified in $R$. similis include those involved in plant cell wall modification such as $\beta$-1,4-endoglucanase, pectate lyase, endoxylanase, arabinase, and expansins and in parasitism, genes were identified in few root-lesion nematodes such as SXP/RAL-2, FAR and chorismate mutase. Proteinase-coding genes such as serine carboxypeptidase, calreticulin, and cathepsin that have been linked to different aspects of plant parasitism were also identified in $R$. similis $[58,59,61,69]$. Similar to 
few root-lesion nematodes, homologues of sequences involved in sedentary endoparasitism such as CLE, CEP, 16D10, and 7E12 were absent in R. similis. Several gene sequences coding for SPRY domains were identified in the genome analysis. However, no N-terminal signal peptides were found in these proteins. Another notable finding in the $R$. similis genome, as well as transcriptome analysis, is the presence of several genes involved in the dauer pathway. A study by Chabrier et al. demonstrated after 180 days under no host conditions, $R$. similis males increased in number $(21.7 \%)$ compared to females $(9.8 \%)$, indicating a possibility of higher expression of dauer genes in males than females (or lower survival of females during unfavorable conditions, and hence a lower expression of dauer genes) [74].

The recent genome analysis of $R$. similis has also shed more light into the relationship of this migratory nematode with the sedentary cyst nematodes. A recent robust phylogenetic analysis of the small subunit ribosomal DNA (SSU rDNA) by Holterman et al. revealed five lineages leading to sedentary endoparasitism. Among these, the subfamilies Pratylenchinae and Hirschmanniellinae were hypothesized as ancestors of the sedentary root-knot nematodes. Additionally, a common ancestral link between the semi-endoparasitic nematode, Rotylenchulus reniformis Linford and Oliveira, 1940 and the endoparasitic cyst nematodes has also been suggested by rDNA analysis as well as the effector analysis $[75,76]$. In the same phylogenetic analysis, it can be noted that $R$. similis and the members of the genus Heterodera, Globodera, and Rotylenchulus share a common ancestor. However, although it is relatively phylogenetically close, $R$. similis shares no overlap of key effectors such as CLE and SPRYSEC with the sedentary cyst nematodes. Holterman et al. also demonstrated the close association between members of the Radopholus genus, specifically $R$. bridgei and R. similis with Hoplolaimus femina. Hoplolaimus is comprised of phytonematodes with a wide range of lifestyle (ecto, endo, and semi-endoparasites) [77]. However, limited information is available regarding the molecular interactions governing parasitism for this nematode (Hoplolaimus genus) or the similarity/differences of effector repertoire between the other two Radopholus species (R. bridgei Siddiqi and Hahn, 1995 and R. similis).

\subsection{Ditylenchus spp.}

Expressed sequence tag (EST) analyses has been used previously to identify several genes involved in parasitism in the root-knot and cyst forming nematodes $[78,79]$. EST analysis of the potato rot nematode, $D$. destructor, revealed homologs of several important effectors such as VAP and calreticulin, which play vital roles in host defense induction. Moreover, effectors involved in circumventing host defense in cyst nematodes such as SEC-2 proteins and numerous cell wall modifying enzymes, such as pectate lyase, cellulase, and expansin, were also identified in D. destructor [63,70]. Additionally, 14-3-3b a secretory protein identified in the gland cell of M. incognita (Kofoid and White, 1919) Chitwood, 1949 and implicated in playing an essential role in signal transduction pathways, has also been identified in the EST dataset of D. destructor $[63,80]$. Since $D$. destructor feeds on fungi as well, it is unsurprising that proteins involved in fungal cell wall degradation, such as chitinases and GH16 (1-3(4))-beta-glucanase genes, were identified in the EST dataset of this nematode.

EST analysis of the peanut pod nematode, D. africanus Wendt, Swart, Vrain, and Webster, 1995, identified a similar suite of expressed parasitism genes [81]. Homologs of key genes participating in anhydrobiosis, such as the late embryogenesis abundant protein (LEA), were also identified in D. africanus. This is on par with certain members of the genus Ditylenchus, such as D. dipsaci, which have been shown to be capable of anhydrobiosis [82]. Genes involved in providing structural integrity to the nematode cell membrane, such as fatty acid desaturase and stomatin, were also identified in the EST dataset [81].

\subsection{Bursaphelenchus spp.}

Analysis of over 13,000 and 3000 ESTs from B. xylophilus and B. mucronatus (Mamiya and Enda, 1979), respectively, revealed several genes involved in parasitism [83]. In addition to the conventional parasitism genes, genes such as chitinase, expressed in the esophageal gland cells of the cyst nematode, 
have also been found in B. xylophilus [83,84]. Presence of this and other chitin degrading enzymes, like GH16, are necessary because Bursaphelenchus feeds on fungi (cell wall made of chitin) and is vectored by Monochamus insects (insect cuticle is made of chitin). Additionally, with D. africanus, the authors found several dauer genes such as LEA homologs as well as 18 Caenorhabditis elegans (Maupas, 1899) dauer-formation (daf) homologs. Identification and characterization of parasitism genes has led to the discovery of a multilayered enzymatic detoxification strategy in B. xylophilus, with detoxification enzymes such as glutathione S-transferase being secreted as the first line of response, and other parasitism effectors such as VAP being secreted later [66]. Detoxification enzymes such as glutathione S-transferase have been shown to play significant roles towards plant parasitism in root-knot nematodes [66,85]. Recently, the effector gene, BxSapB1, has been identified in B. xylophilus [66]. $B x$ SapB1 possesses a functional signal peptide and has been demonstrated to contribute towards host cell death and increased virulence of B. xylophilus [64].

\section{Management of Migratory PPNs}

A variety of management strategies has been employed for different types of PPN due to their ability to parasitize a wide range of hosts. Migratory PPNs such as those belonging to the genera Radopholus, Ditylenchus, and Pratylenchus can be easily spread by contaminated vegetative plant parts and timber (in the case of B. xylophilus) [86]. Integrating multiple management strategies is essential; however, the specific strategy should depend upon accurate diagnosis of the PPN species, growing conditions, available resources, and economic feasibility, which vary among cropping systems and in developing vs. developed countries.

\subsection{Cultural Practices}

Cultural practices such as crop rotation with a non-host crop or instituting a period of fallow (including elimination of weeds), can reduce nematode populations. Crop rotation is less effective as a control strategy, however, due to the polyphagous nature of some PPNs. For instance, rotation with crops such as cassava (Manihot esculenta) and sweetpotato (Ipomoea batatas) has been useful in bringing down R. similis populations [87], but sweet potato is a susceptible host for other types of PPN such as M. enterolobii Yang and Eisenback, 1981 and Rotylenchulus reniformis. However, in the case of $P$. zeae, effective control has been achieved by rotating rice with leguminous beans such as black gram (Vigna Mungo (L.) Hepper) and mung bean (Vigna radiata (L.) R. Wilczek) [88]. Control of another lesion nematode, $P$. thornei in wheat (Triticum aestivum), was also achieved in Mexico by rotating with crops such as cotton (Gossypium spp.), corn (Zea mays), and soybean (Glycine max) for two successive years [89]. The use of certified nematode-free starting material such as seed potato (Solanum tuberosum) or banana (Musa spp.) corm has been helpful in reducing nematode populations of $D$. dipsaci and $R$. similis, respectively [90-92]. Use of clean starting material has also been effective in reducing populations of the yam nematode $S$. bradys, the causative agent of dry rot disease in yams. Utilizing hot water treatment for disinfecting starting plant material has been useful for managing populations of D. dipsaci, P. vulnus, and R. similis [90-92].

Cover crops are an indispensable unit in an agricultural ecosystem since they provides a host of benefits to the soil such as increased nutrients, reduced pest populations, as well as an increase in beneficial soil microbes. Use of marigold (Tagetes spp.), which has been shown to produce thiophene $\alpha$ terthienyl (a nematicidal compound), as a cover crop has provided effective control against $P$. penetrans [93-96]. Sunn hemp (Crotalaria juncea L.), a leguminous cover crop, has also shown significant potential in reducing populations of several sedentary nematodes of the Meloidogyne and Heterodera genera as well as migratory nematodes such as the sting nematode (Belonolaimus longicaudatus Rau, 1958) and stubby root nematodes (Paratrichodorus and Trichodorus spp.) $[97,98]$. Moreover, recent studies with sunn hemp, pigeon pea (Cajanus cajan), and Gliricidia sepium have delivered promising results in managing the endoparasitic yam nematode, S. bradys [99]. However, a recent trial with sunn hemp and pigeon pea showed no nematode suppression activity on the migratory 
nematode $R$. similis [100]. In addition, cover crops such as mustard (Brassica and Sinapis spp.) contain a wide variety of PPN antagonistic compounds such as isothiocyanates and degradation products of glucosinolates, which have provided moderate nematode suppression effects [101]. For a detailed review of phytochemicals for nematode control, the authors recommend Chitwood [102].

\subsection{Resistance as a Tool for Nematode Control}

Due to the growing environmental and human health concerns caused by the use of toxic nematicides and the associated regulations surrounding their use, incorporating natural resistance (R) genes into desirable crop cultivars has been a successful strategy to provide crop protection against PPNs [103]. The first cloned naturally occurring $R$ gene that provided resistance against a PPN was the Hs1 ${ }^{\text {pro1 }}$ gene from sugar beet (Beta vulgaris) $[104,105]$. This gene confers resistance to the sedentary cyst-forming nematode, $H$. schachtii [104]. Since then, many nematode $\mathrm{R}$ genes have been cloned and identified including Mi-1, Hero A, Gpa2, Gro1-4, Rhg1, and Rhg4; however, these genes confer resistance only to sedentary PPNs [106-112].

With regards to migratory nematodes, Atkinson et al. (2004) [113] demonstrated the efficacy of the first transgenic bananas expressing rice cystatins which provided significant resistance (around $70 \% \pm 10 \%$ ) against $R$. similis. Transgenic Nicotiana benthamiana plants expressing the cysteine proteinase cathepsin $S$ also demonstrated enhanced resistance to $R$. similis [114]. Musa varieties such as the Yangambi Km5 and Pisang Jari Buaya also provide some degree of resistance against $R$. similis, primarily through mechanisms involving phenol accumulation and lignification, respectively, at the nematode infection site $[115,116]$. Furthermore, evidence of a mutualistic Fusarium endophyte (Fusarium oxysporum isolate A1 and Fusarium cf. diversisporum) inducing systemic resistance against $R$. similis in bananas has also been demonstrated [117]. Another instance of resistance against a migratory PPN is the bread wheat line Gatcher selection 50a, which provides partial resistance against the root lesion nematode $P$. thornei [118]. Partial resistance to $P$. thornei has also been identified in other varieties of wheat such as "CPI133872", grown in multiple regions in Australia, where P. thornei is an extremely damaging pathogen [119-121]. Although, several trials on potato varieties have been conducted to identify sources of resistance or tolerance ('tolerance" as defined by Mwaura et al.) against nematodes in the Ditylenchus genus, few varieties are commercially available [122]. In a recent study based on the relative susceptibility score, the potato variety "Spunta" was classified as resistant against D. destructor and D. dipsaci under greenhouse conditions [122]. However, these results have not been confirmed under field conditions.

\subsection{Nematicides}

Due to the deleterious effects of certain nematicides/pesticides on the environment and non-target organisms, severe regulatory restrictions including the ban of important nematicides have been established. One such broad spectrum pesticide, methyl bromide, which is also a popular fumigant nematicide, was phased out of agricultural use in the United States in 2005 due to its atmospheric ozone depletion properties [123-125]. Currently there exists a huge gap in the number of effective and economical nematicide products that are available to growers. Some of the important fumigant nematicides currently approved for use on high-value crops and ornamentals in the United States include metam sodium (Vapam ${ }^{\circledR}$ ), metam potassium (Metam CLR ${ }^{\mathrm{TM}}$ ), chloropicrin (Metapicrin), and 1,3-dichloropropene (Telone $\left.{ }^{\circledR}\right)$ [125]. An alternative to methyl bromide with regards to the lowest per-unit cost is the registered fumigant chloropicrin, which has been used in combination with the fumigant nematicide 1,3-D [126]. This combination treatment has provided effective control against soilborne pathogens in a broad variety of crops such as almonds (Prunus dulcis, syn. Prunus amygdalus), sweetpotatoes, strawberries (Fragaria anannasa), grapes (Vitis vinifera), and carrots (Daucus carota subsp. sativus), but limited control of weeds and high input costs concern many growers. Additionally, application of 1,3-D has been restricted within California townships, with a ban of 1,3-D in the month of December due to air quality concerns $[127,128]$. Another example is the non-fumigant 
nematicide, fenamiphos (Nemacur $\left.{ }^{\circledR}\right)$. Fenamiphos has been utilized by Anthurium growers in Hawaii as a post-plant application for managing $R$. similis and other PPNs [129]. However, with a phase-out of this chemical in the U.S., growers are now integrating cleaner management practices such as using micropropogated Anthurium plantlets and disinfested starting materials [130]. An alternative microbial nematicide, DiTera ${ }^{\circledR}$ (nematicide synthesized from the fungus Myrothecium verrucaria) has also been recommended as an effective low-risk nematicide for reducing $R$. similis populations in Anthurium [130]. In a recent study by Zouhar et al., treatment of garlic (Allium sativum) cloves with the fumigant hydrogen cyanide at a concentration of $20 \mathrm{~g} / \mathrm{m}^{3}$ caused significant increase in $D$. dipsaci mortality [131].

Post-plant application of the systemic nonfumigant nematicide oxamyl (Vydate ${ }^{\circledR}$ ) has provided effective control against the root-lesion nematode, P. penetrans, in raspberries (Rubus idaeus) during field trials in Washington [132]. Another nonfumigant nematicide that has been registered in several countries for crop protection against multiple nematodes, predominantly the root-lesion, potato rot, and pine wood nematode, is the contact nematicide fosthiazate (Nemathorin ${ }^{\circledR}$ ) [133]. Migratory PPNs such as root-lesion nematodes generally occur as a complex with other plant-pathogens such as Fusarium spp. [134]. Trials with a combination of abamectin-fungicide coated seeds reduced root infection by P. penetrans in maize [135]. Seed treatments are also an important form of control for the stem and bulb nematode D. dipsaci [131]. Novel seed treatment strategies such as electrospinning of agrichemicals has also recently shown promise to manage plant pathogens under laboratory conditions [136]. Essential oils and volatiles derived from several families of Portuguese aromatic flora have also shown effective nematicidal properties against the pine-wilt nematode B. xylophilus [137]. Although, several significant nematicides have been phased out and severe regulations have been imposed on some of the remaining ones, a management strategy combining multiple control practices should be practiced for effective nematode control.

\section{Conclusions}

Migratory PPNs are distributed across multiple clades in the phylum Nematoda. Although there exist similarities in the biology and life cycle of several migratory PPNs, huge contrasts and divergences are seen with respect to the anatomical adjustments made to survive in the absence of a viable host. Parallel evolution of feeding enzymes that allow successful feeding in the host cells and on other microbes such as fungi is a trait that has undergone divergence several times in the course of evolution of migratory PPNs in the Nematoda lineage. By coupling spatio-temporal NGS approaches with molecular/functional characterization studies, insights into some of the key effectors and their targets can be gained, which shed light on the multifaceted interaction of a PPN with its host. Migratory PPNs, like their sedentary counterparts, have been distributed across the globe, probably as a result of increased international trade. A multipronged control strategy that depends less on chemical means and integrates factors such as the geographical location, nematode species and host range, plant resistance, as well as sound agricultural practices should be considered during the decision-making process for managing any plant-parasitic nematode.

Author Contributions: R.M. and C.H.O. All authors have read and agreed to the published version of the manuscript.

Funding: Funding was provided by the Bill and Melinda Gates Foundation.

Acknowledgments: The authors would like to thank Reenah Schaffer for proof-reading and editing the manuscript.

Conflicts of Interest: The authors declare no conflict of interest. 


\section{References}

1. Decraemer, W.; Hunt, D. Plant nematology. In Structure and Classification; Perry, R.N., Moens, M., Eds.; CABI: Cambridge, MA, USA, 2006; pp. 3-32.

2. Abad, P.; Gouzy, J.; Aury, J.-M.; Castagnone-Sereno, P.; Danchin, E.G.; Deleury, E.; Perfus-Barbeoch, L.; Anthouard, V.; Artiguenave, F.; Blok, V.C. Genome sequence of the metazoan plant-parasitic nematode Meloidogyne incognita. Nat. Biotechnol. 2008, 26, 909. [CrossRef] [PubMed]

3. Nicol, J.M.; Turner, S.J.; Coyne, D.L.; Den Nijs, L.; Hockland, S.; Maafi, Z.T.; Jones, J.T.; Gheysen, G.; Fenoll, C. Genomics and molecular genetics of plant-nematode interactions. Curr. Nematode Threats Word Agric. Cap 2011, 2, 21-26.

4. Hass, H.; Kerp, H.; Poinar, G. Palaeonema phyticum gen. n., sp. n.(Nematoda: Palaeonematidae fam. n.), a Devonian nematode associated with early land plants. Nematology 2008, 10, 9-14. [CrossRef]

5. Smant, G.; Helder, J.; Goverse, A. Parallel adaptations and common host cell responses enabling feeding of obligate and facultative plant parasitic nematodes. Plant J. 2018, 93, 686-702. [CrossRef]

6. Holterman, M.; van der Wurff, A.; van den Elsen, S.; van Megen, H.; Bongers, T.; Holovachov, O.; Bakker, J.; Helder, J. Phylum-wide analysis of SSU rDNA reveals deep phylogenetic relationships among nematodes and accelerated evolution toward crown clades. Mol. Biol. Evol. 2006, 23, 1792-1800. [CrossRef]

7. Giblin-Davis, R.M.; Davies, K.A.; Morris, K.; Thomas, W.K. Evolution of parasitism in insect-transmitted plant nematodes. J. Nematol. 2003, 35, 133.

8. Kikuchi, T.; Eves-van den Akker, S.; Jones, J.T. Genome evolution of plant-parasitic nematodes. Annu. Rev. Phytopathol. 2017, 55, 333-354. [CrossRef]

9. Bird, D.M.; Jones, J.T.; Opperman, C.H.; Kikuchi, T.; Danchin, E.G. Signatures of adaptation to plant parasitism in nematode genomes. Parasitology 2015, 142, S71-S84. [CrossRef]

10. Mitchum, M.G.; Hussey, R.S.; Baum, T.J.; Wang, X.; Elling, A.A.; Wubben, M.; Davis, E.L. Nematode effector proteins: An emerging paradigm of parasitism. New Phytol. 2013, 199, 879-894. [CrossRef]

11. Coyne, D.L.; Cortada, L.; Dalzell, J.J.; Claudius-Cole, A.O.; Haukeland, S.; Luambano, N.; Talwana, H. Plant-Parasitic Nematodes and Food Security in Sub-Saharan Africa. Annu. Rev. Phytopathol. 2018, 56, 381-403. [CrossRef]

12. FAOSTAT. Available online: http://www.fao.org/faostat/en/\#rankings/countries_by_commodity (accessed on 20 September 2019).

13. Yusuf, A.; Claudius-Cole, A.O. Evaluation of Culturing Methods for the Yam Nematode Scutellonema bradys. J. Exp. Agric. Int. 2018, 1-8. [CrossRef]

14. Huang, X.; Xu, C.-L.; Yang, S.-H.; Li, J.-Y.; Wang, H.-L.; Zhang, Z.-X.; Chen, C.; Xie, H. Life-stage specific transcriptomes of a migratory endoparasitic plant nematode, Radopholus similis elucidate a different parasitic and life strategy of plant parasitic nematodes. Sci. Rep. 2019, 9, 6277. [CrossRef] [PubMed]

15. Fosu-Nyarko, J.; Tan, J.-A.C.; Gill, R.; Agrez, V.G.; Rao, U.; Jones, M.G. D e novo analysis of the transcriptome of Pratylenchus zeae to identify transcripts for proteins required for structural integrity, sensation, locomotion and parasitism. Mol. Plant Pathol. 2016, 17, 532-552. [CrossRef] [PubMed]

16. Vieira, P.; Eves-Van Den Akker, S.; Verma, R.; Wantoch, S.; Eisenback, J.D.; Kamo, K. The Pratylenchus penetrans transcriptome as a source for the development of alternative control strategies: Mining for putative genes involved in parasitism and evaluation of in planta RNAi. PLoS ONE 2015, 10, e0144674. [CrossRef] [PubMed]

17. Haegeman, A.; Joseph, S.; Gheysen, G. Analysis of the transcriptome of the root lesion nematode Pratylenchus coffeae generated by 454 sequencing technology. Mol. Biochem. Parasitol. 2011, 178, 7-14. [CrossRef] [PubMed]

18. Jacob, J.; Mitreva, M.; Vanholme, B.; Gheysen, G. Exploring the transcriptome of the burrowing nematode Radopholus similis. Mol. Genet. Genom. 2008, 280, 1-17. [CrossRef] [PubMed]

19. Mathew, R.; Opperman, C.H. The genome of the migratory nematode, Radopholus similis, reveals signatures of close association to the sedentary cyst nematodes. PLoS ONE 2019, 14, e0224391. [CrossRef] [PubMed]

20. Mathew, R.; Burke, M.; Opperman, C.H. A Draft Genome Sequence of the Burrowing Nematode Radopholus similis. J. Nematol. 2019, 51, e2019-51. [CrossRef]

21. Juvale, P.S.; Baum, T.J. “Cyst-ained” research into Heterodera parasitism. PLoS Pathog. 2018, 14, e1006791. [CrossRef] [PubMed] 
22. Vieira, P.; Gleason, C. Plant-parasitic nematode effectors-Insights into their diversity and new tools for their identification. Curr. Opin. Plant Biol. 2019, 50, 37-43. [CrossRef]

23. Jones, J.T.; Haegeman, A.; Danchin, E.G.; Gaur, H.S.; Helder, J.; Jones, M.G.; Kikuchi, T.; Manzanilla-López, R.; Palomares-Rius, J.E.; Wesemael, W.M. Top 10 plant-parasitic nematodes in molecular plant pathology. Mol. Plant Pathol. 2013, 14, 946-961. [CrossRef] [PubMed]

24. Kikuchi, T.; Cotton, J.A.; Dalzell, J.J.; Hasegawa, K.; Kanzaki, N.; McVeigh, P.; Takanashi, T.; Tsai, I.J.; Assefa, S.A.; Cock, P.J. Genomic insights into the origin of parasitism in the emerging plant pathogen Bursaphelenchus xylophilus. PLoS Pathog. 2011, 7, e1002219. [CrossRef] [PubMed]

25. Kanzaki, N.; Tanaka, R.; Giblin-Davis, R.M.; Davies, K.A. New plant-parasitic nematode from the mostly mycophagous genus Bursaphelenchus discovered inside figs in Japan. PLoS ONE 2014, 9, e99241. [CrossRef]

26. Castillo, P.; Vovlas, N. Pratylenchus (Nematoda: Pratylenchidae): Diagnosis, Biology, Pathogenicity and Management; Brill: Leiden-Boston, MA, USA, 2007; ISBN 90-474-2401-8.

27. CABI. In: EPPO Bulletin. 2019. Available online: www.cabi.org/isc (accessed on 1 November 2019).

28. Perry, R.N.; Wharton, D.A. Molecular and Physiological Basis of Nematode Survival; CABI: Cambridge, MA, USA, 2011; ISBN 1-84593-711-2.

29. Braasch, H. Bursaphelenchus species in conifers in Europe: Distribution and morphological relationships. EPPO Bull. 2001, 31, 127-142. [CrossRef]

30. Liu, Z.; Li, Y.; Pan, L.; Meng, F.; Zhang, X. Cold adaptive potential of pine wood nematodes overwintering in plant hosts. Biol. Open 2019, 8, bio041616. [CrossRef]

31. Han, Z.; Boas, S.; Schroeder, N.E. Serotonin regulates the feeding and reproductive behaviors of Pratylenchus penetrans. Phytopathology 2017, 107, 872-877. [CrossRef]

32. Karakaş, M. Penetration and Feeding Behavior of Pratylenchus penetrans (Nematoda: Pratylenchidae) In Red Radish Roots. Kafkas Üniversitesi Fen Bilimleri Enstitüsü Dergisi 2009, 2, 31-36.

33. Kurppa, S.; Vrain, T.C. Penetration and feeding behavior of Pratylenchus penetrans in strawberry roots. Rev. Nématologie 1985, 8, 273-276.

34. Rebois, R.V.; Huettel, R.N. Population dynamics, root penetration, and feeding behavior of Pratylenchus agilis in monoxenic root cultures of corn, tomato, and soybean. J. Nematol. 1986, 18, 392. [PubMed]

35. Zunke, U. Observations on the invasion and endoparasitic behavior of the root lesion nematode Pratylenchus penetrans. J. Nematol. 1990, 22, 309. [PubMed]

36. Zunke, U. Ectoparasitic feeding behaviour of the root lesion nematode, Pratylenchus penetrans, on root hairs of different host plants. Rev. Nématologie 1990, 13, 331-337.

37. Fosu-Nyarko, J.; Jones, M.G. Advances in understanding the molecular mechanisms of root lesion nematode host interactions. Annu. Rev. Phytopathol. 2016, 54, 253-278. [CrossRef] [PubMed]

38. Haegeman, A.; Vanholme, B.; Gheysen, G. Characterization of a putative endoxylanase in the migratory plant-parasitic nematode Radopholus similis. Mol. Plant Pathol. 2009, 10, 389-401. [CrossRef] [PubMed]

39. Haegeman, A.; Jacob, J.; Vanholme, B.; Kyndt, T.; Gheysen, G. A family of GHF5 endo-1, 4-beta-glucanases in the migratory plant-parasitic nematode Radopholus similis. Plant Pathol. 2008, 57, 581-590. [CrossRef]

40. Kikuchi, T.; Shibuya, H.; Aikawa, T.; Jones, J.T. Cloning and characterization of pectate lyases expressed in the esophageal gland of the pine wood nematode Bursaphelenchus xylophilus. Mol. Plant-Microbe Interact. 2006, 19, 280-287. [CrossRef]

41. Kikuchi, T.; Jones, J.T.; Aikawa, T.; Kosaka, H.; Ogura, N. A family of glycosyl hydrolase family 45 cellulases from the pine wood nematode Bursaphelenchus xylophilus. FEBS Lett. 2004, 572, 201-205. [CrossRef]

42. Momota, Y.; Uehara, T.; Kushida, A. PCR-based cloning of two $\Xi-1$, 4-endoglucanases from the root-lesion nematode Pratylenchus penetrans. Nematology 2001, 3, 335-341. [CrossRef]

43. Rybarczyk-Mydłowska, K.; Maboreke, H.R.; van Megen, H.; van den Elsen, S.; Mooyman, P.; Smant, G.; Bakker, J.; Helder, J. Rather than by direct acquisition via lateral gene transfer, GHF5 cellulases were passed on from early Pratylenchidae to root-knot and cyst nematodes. BMC Evol. Biol. 2012, 12, 221. [CrossRef]

44. Fanelli, E.; Troccoli, A.; Picardi, E.; Pousis, C.; De Luca, F. Molecular characterization and functional analysis of four $\beta-1,4$-endoglucanases from the root-lesion nematode Pratylenchus vulnus. Plant Pathol. 2014, 63, 1436-1445. [CrossRef]

45. Vieira, P.; Maier, T.R.; Eves-van den Akker, S.; Howe, D.K.; Zasada, I.; Baum, T.J.; Eisenback, J.D.; Kamo, K. Identification of candidate effector genes of Pratylenchus penetrans. Mol. Plant Pathol. 2018, 19, 1887-1907. [CrossRef] 
46. Peetz, A.B.; Zasada, I.A. Species-specific diagnostics using a $\beta-1$, 4-endoglucanase gene for Pratylenchus spp. occurring in the Pacific Northwest of North America. Nematology 2016, 18, 1219-1229. [CrossRef]

47. Davis, E.L.; Haegeman, A.; Kikuchi, T. Degradation of the Plant Cell Wall by Nematodes. In Genomics and Molecular Genetics of Plant-Nematode Interactions; Jones, J., Gheysen, G., Fenoll, C., Eds.; Springer: Dordrecht, The Netherlands, 2011; pp. 255-272. ISBN 978-94-007-0434-3. [CrossRef]

48. De Boer, J.M.; Davis, E.L.; Hussey, R.S.; Popeijus, H.; Smant, G.; Baum, T.J. Cloning of a putative pectate lyase gene expressed in the subventral esophageal glands of Heterodera glycines. J. Nematol. 2002, $34,9$. [PubMed]

49. Doyle, E.A.; Lambert, K.N. Cloning and characterization of an esophageal-gland-specific pectate lyase from the root-knot nematode Meloidogyne javanica. Mol. Plant-Microbe Interact. 2002, 15, 549-556. [CrossRef] [PubMed]

50. Huang, G.; Dong, R.; Allen, R.; Davis, E.L.; Baum, T.J.; Hussey, R.S. Developmental expression and molecular analysis of two Meloidogyne incognita pectate lyase genes. Int. J. Parasitol. 2005, 35, 685-692. [CrossRef] [PubMed]

51. Kudla, U.; MILAC, A.-L.; Qin, L.; Overmars, H.; Roze, E.; Holterman, M.; PETRESCU, A.-J.; Goverse, A.; Bakker, J.; Helder, J. Structural and functional characterization of a novel, host penetration-related pectate lyase from the potato cyst nematode Globodera rostochiensis. Mol. Plant Pathol. 2007, 8, 293-305. [CrossRef] [PubMed]

52. Popeijus, H.; Overmars, H.; Jones, J.; Blok, V.; Goverse, A.; Helder, J.; Schots, A.; Bakker, J.; Smant, G. Enzymology: Degradation of plant cell walls by a nematode. Nature 2000, 406, 36. [CrossRef]

53. Zheng, J.; Peng, D.; Chen, L.; Liu, H.; Chen, F.; Xu, M.; Ju, S.; Ruan, L.; Sun, M. The Ditylenchus destructor genome provides new insights into the evolution of plant parasitic nematodes. Proc. R. Soc. B 2016, 283, 20160942. [CrossRef]

54. Williamson, V.M.; Gleason, C.A. Plant-nematode interactions. Curr. Opin. Plant Biol. 2003, 6, 327-333. [CrossRef]

55. Vanholme, B.; Van Thuyne, W.; Vanhouteghem, K.; De Meutter, J.A.N.; Cannoot, B.; Gheysen, G. Molecular characterization and functional importance of pectate lyase secreted by the cyst nematode Heterodera schachtii. Mol. Plant Pathol. 2007, 8, 267-278. [CrossRef]

56. Mitreva-Dautova, M.; Roze, E.; Overmars, H.; de Graaff, L.; Schots, A.; Helder, J.; Goverse, A.; Bakker, J.; Smant, G. A symbiont-independent endo-1, 4- $\beta$-xylanase from the plant-parasitic nematode Meloidogyne incognita. Mol. Plant-Microbe Interact. 2006, 19, 521-529. [CrossRef]

57. Hogenhout, S.A.; Van der Hoorn, R.A.; Terauchi, R.; Kamoun, S. Emerging concepts in effector biology of plant-associated organisms. Mol. Plant-Microbe Interact. 2009, 22, 115-122. [CrossRef] [PubMed]

58. Huang, X.; Xu, C.-L.; Chen, W.-Z.; Chen, C.; Xie, H. Cloning and characterization of the first serine carboxypeptidase from a plant parasitic nematode, Radopholus similis. Sci. Rep. 2017, 7, 4815. [CrossRef] [PubMed]

59. Wang, K.; Li, Y.; Huang, X.; Wang, D.; Xu, C.; Xie, H. The cathepsin S cysteine proteinase of the burrowing nematode Radopholus similis is essential for the reproduction and invasion. Cell Biosci. 2016, 6, 39. [CrossRef] [PubMed]

60. Li, Y.; Wang, K.; Xie, H.; Wang, D.-W.; Xu, C.-L.; Huang, X.; Wu, W.-J.; Li, D.-L. Cathepsin B cysteine proteinase is essential for the development and pathogenesis of the plant parasitic nematode Radopholus similis. Int. J. Biol. Sci. 2015, 11, 1073. [CrossRef] [PubMed]

61. Li, Y.; Wang, K.; Xie, H.; Wang, Y.-T.; Wang, D.-W.; Xu, C.-L.; Huang, X.; Wang, D.-S. A nematode calreticulin, Rs-CRT, is a key effector in reproduction and pathogenicity of Radopholus similis. PLoS ONE 2015, 10, e0129351. [CrossRef]

62. Zhang, C.; Xie, H.; Cheng, X.; Wang, D.-W.; Li, Y.; Xu, C.-L.; Huang, X. Molecular identification and functional characterization of the fatty acid-and retinoid-binding protein gene Rs-far- 1 in the burrowing nematode Radopholus similis (Tylenchida: Pratylenchidae). PLoS ONE 2015, 10, e0118414. [CrossRef]

63. Peng, H.; Gao, B.; Kong, L.; Yu, Q.; Huang, W.; He, X.; Long, H.; Peng, D. Exploring the host parasitism of the migratory plant-parasitic nematode Ditylenchus destuctor by expressed sequence tags analysis. PLoS ONE 2013, 8, e69579. [CrossRef] 
64. Hu, L.-J.; Wu, X.-Q.; Li, H.-Y.; Zhao, Q.; Wang, Y.-C.; Ye, J.-R. An Effector, BxSapB1, Induces Cell Death and Contributes to Virulence in the Pine Wood Nematode Bursaphelenchus xylophilus. Mol. Plant-Microbe Interact. 2019, 32, 452-463. [CrossRef]

65. Shinya, R.; Morisaka, H.; Kikuchi, T.; Takeuchi, Y.; Ueda, M.; Futai, K. Secretome analysis of the pine wood nematode Bursaphelenchus xylophilus reveals the tangled roots of parasitism and its potential for molecular mimicry. PLoS ONE 2013, 8, e67377. [CrossRef]

66. Espada, M.; Silva, A.C.; Eves van den Akker, S.; Cock, P.J.; Mota, M.; Jones, J.T. Identification and characterization of parasitism genes from the pinewood nematode Bursaphelenchus xylophilus reveals a multilayered detoxification strategy. Mol. Plant Pathol. 2016, 17, 286-295. [CrossRef]

67. Kang, J.S.; Koh, Y.H.; Moon, Y.S.; Lee, S.H. Molecular properties of a venom allergen-like protein suggest a parasitic function in the pinewood nematode Bursaphelenchus xylophilus. Int. J. Parasitol. 2012, 42, 63-70. [CrossRef] [PubMed]

68. Iberkleid, I.; Vieira, P.; de Almeida Engler, J.; Firester, K.; Spiegel, Y.; Horowitz, S.B. Fatty acid-and retinol-binding protein, Mj-FAR-1 induces tomato host susceptibility to root-knot nematodes. PLoS ONE 2013, 8, e64586. [CrossRef] [PubMed]

69. Jacob, J.; Vanholme, B.; Haegeman, A.; Gheysen, G. Four transthyretin-like genes of the migratory plant-parasitic nematode Radopholus similis: Members of an extensive nematode-specific family. Gene 2007, 402, 9-19. [CrossRef] [PubMed]

70. Prior, A.; Jones, J.T.; Beauchamp, J.; McDermott, L.; Cooper, A.; Kennedy, M.W. A surface-associated retinol-and fatty acid-binding protein (Gp-FAR-1) from the potato cyst nematode Globodera pallida: Lipid binding activities, structural analysis and expression pattern. Biochem. J. 2001, 356, 387-394. [CrossRef] [PubMed]

71. Moffett, P.; Ali, S.; Magne, M.; Chen, S.; Obradovic, N.; Jamshaid, L.; Wang, X.; Bélair, G. Analysis of Globodera rostochiensis effectors reveals conserved functions of SPRYSEC proteins in suppressing and eliciting plant immune responses. Front. Plant Sci. 2015, 6, 623.

72. De Waele, D.; Elsen, A. Challenges in tropical plant nematology. Annu. Rev. Phytopathol. 2007, 45, 457-485. [CrossRef]

73. Perry, R.N.; Moens, M. Plant Nematology; CABI: Cambridge, MA, USA, 2006; ISBN 1-84593-057-6.

74. Chabrier, C.; Tixier, P.; Duyck, P.-F.; Cabidoche, Y.-M.; Quénéhervé, P. Survival of the burrowing nematode Radopholus similis (Cobb) Thorne without food: Why do males survive so long? Appl. Soil Ecol. 2010, 45, 85-91. [CrossRef]

75. Holterman, M.; Karegar, A.; Mooijman, P.; van Megen, H.; van den Elsen, S.; Vervoort, M.T.; Quist, C.W.; Karssen, G.; Decraemer, W.; Opperman, C.H. Disparate gain and loss of parasitic abilities among nematode lineages. PLoS ONE 2017, 12, e0185445. [CrossRef]

76. Wubben, M.J.; Ganji, S.; Callahan, F.E. Identification and molecular characterization of a $\beta-1,4$-endoglucanase gene (Rr-eng-1) from Rotylenchulus reniformis. J. Nematol. 2010, 42, 342.

77. Bae, C.; Szalanski, A.; Robbins, R. Molecular Analysis of the Lance Nematode, Hoplolaimus spp., Using the First Internal Transcribed Spacer and the D1-D3 Expansion Segments of 28S Ribosomal DNA1. J. Nematol. 2008, 40, 201-209.

78. Jones, J.T.; Furlanetto, C.; Bakker, E.; Banks, B.; Blok, V.; Chen, Q.; Phillips, M.; Prior, A. Characterization of a chorismate mutase from the potato cyst nematode Globodera pallida. Mol. Plant Pathol. 2003, 4, 43-50. [CrossRef] [PubMed]

79. Rosso, M.-N.; Favery, B.; Piotte, C.; Arthaud, L.; De Boer, J.M.; Hussey, R.S.; Bakker, J.; Baum, T.J.; Abad, P. Isolation of a cDNA encoding a $\beta-1,4$-endoglucanase in the root-knot nematode Meloidogyne incognita and expression analysis during plant parasitism. Mol. Plant-Microbe Interact. 1999, 12, 585-591. [CrossRef] [PubMed]

80. Jaubert, S.; Laffaire, J.-B.; Ledger, T.N.; Escoubas, P.; Amri, E.-Z.; Abad, P.; Rosso, M.N. Comparative analysis of two 14-3-3 homologues and their expression pattern in the root-knot nematode Meloidogyne incognita. Int. J. Parasitol. 2004, 34, 873-880. [CrossRef] [PubMed]

81. Haegeman, A.; Jacob, J.; Vanholme, B.; Kyndt, T.; Mitreva, M.; Gheysen, G. Expressed sequence tags of the peanut pod nematode Ditylenchus africanus: The first transcriptome analysis of an Anguinid nematode. Mol. Biochem. Parasitol. 2009, 167, 32-40. [CrossRef] [PubMed] 
82. Nema Wool—ZooTerms (Dictionary of Invertebrate Zoology). Available online: https://species-id.net/ zooterms/nema_wool (accessed on 23 March 2020).

83. Kikuchi, T.; Aikawa, T.; Kosaka, H.; Pritchard, L.; Ogura, N.; Jones, J.T. Expressed sequence tag (EST) analysis of the pine wood nematode Bursaphelenchus xylophilus and B. mucronatus. Mol. Biochem. Parasitol. 2007, 155, 9-17. [CrossRef] [PubMed]

84. Gao, B.; Allen, R.; Maier, T.; McDermott, J.P.; Davis, E.L.; Baum, T.J.; Hussey, R.S. Characterisation and developmental expression of a chitinase gene in Heterodera glycines. Int. J. Parasitol. 2002, 32, 1293-1300. [CrossRef]

85. Dubreuil, G.; Magliano, M.; Deleury, E.; Abad, P.; Rosso, M.N. Transcriptome analysis of root-knot nematode functions induced in the early stages of parasitism. New Phytol. 2007, 176, 426-436. [CrossRef]

86. Moens, M.; Perry, R.N. Migratory plant endoparasitic nematodes: A group rich in contrasts and divergence. Annu. Rev. Phytopathol. 2009, 47, 313-332. [CrossRef]

87. Price, N.S. Alternate cropping in the management of Radopholus similis and Cosmopolites sordidus two important pests of banana and plantain. Int. J. Pest Manag. 1994, 40, 237-244. [CrossRef]

88. Prasad, J.S.; Rao, Y.S. Influence of crop rotations on the population densities of the root lesion nematode, Pratylenchus indicus in rice and rice soils. Annales de Zoologie Ecologie Animale 1978, 10, 627-634.

89. Van Gundy, S.D. A pest management approach to the control of Pratylenchus thornei on wheat in Mexico. J. Nematol. 1974, 6, 107. [PubMed]

90. Qiu, J.; Westerdahl, B.B.; Giraud, D.; Anderson, C.A. Evaluation of hot water treatments for management of Ditylenchus dipsaci and fungi in daffodil bulbs. J. Nematol. 1993, 25, 686. [PubMed]

91. Towson, A.J.; Lear, B. Control of nematodes in rose plants by hot-water treatment preceded by heat-hardening. Nematologica 1982, 28, 339-353.

92. Tsang, M.M.C.; Hara, A.H.; Sipes, B. Hot-water treatments of potted palms to control the burrowing nematode, Radopholus similis. Crop Prot. 2003, 22, 589-593. [CrossRef]

93. Alexander, S.A.; Waldenmaier, C.M. Suppression of Pratylenchus penetrans populations in potato and tomato using African marigolds. J. Nematol. 2002, 34, 130.

94. Evenhuis, A.; Korthals, G.; Molendijk, L. Tagetes patula as an effective catch crop for long-term control of Pratylenchus penetrans. Nematology 2004, 6, 877-881. [CrossRef]

95. Kimpinski, J.; Arsenault, W.J.; Gallant, C.E.; Sanderson, J.B. The effect of marigolds (Tagetes spp.) and other cover crops on Pratylenchus penetrans and on following potato crops. J. Nematol. 2000, 32, 531.

96. Pudasaini, M.; Viaene, N.; Moens, M. Effect of marigold (Tagetes patula) on population dynamics of Pratylenchus penetrans in a field. Nematology 2006, 8, 477-484. [CrossRef]

97. Sipes, B.S.; Schmitt, D.P. Crotalaria as a cover crop for nematode management: A review. Nematropica 2002, 32, 35-58.

98. Wang, K.H.; McSorley, R. Management of Nematodes and Soil Fertility with Sunn Hemp Cover Crop; University of Florida IFAS Extension Publication No ENY-717; The Institute of Food and Agricultural Sciences (IFAS): Gainesville, FL, USA, 2004.

99. Moraes, A.d.M.; Muniz, M.; Lima, R.d.S.; Moura Filho, G.; Castro, J.d.C. Organic-Matter Effects on Populations of Dry Rot of Yam Nematodes; Embrapa Semiárido-Artigo em Periódico Indexado (ALICE); Empresa Brasileira de Pesquisa Agropecuária: Brasília, Brazil, 2016.

100. Henmi, V.H.; Marahatta, S.P. Impacts of sunnhemp and pigeon pea on plant-parasitic nematodes, Radopholus similis and Meloidogyne spp. and beneficial bacterivorous nematodes. Int. J. Phytopathol. 2015, 4, $29-33$. [CrossRef]

101. Halbrendt, J.M. Allelopathy in the management of plant-parasitic nematodes. J. Nematol. 1996, $28,8$. [PubMed]

102. Chitwood, D.J. Phytochemical based strategies for nematode control. Annu. Rev. Phytopathol. 2002, 40, 221-249. [CrossRef] [PubMed]

103. Davies, L.J.; Elling, A.A. Resistance genes against plant-parasitic nematodes: A durable control strategy? Nematology 2015, 17, 249-263. [CrossRef]

104. Cai, D.; Kleine, M.; Kifle, S.; Harloff, H.-J.; Sandal, N.N.; Marcker, K.A.; Klein-Lankhorst, R.M.; Salentijn, E.M.; Lange, W.; Stiekema, W.J. Positional cloning of a gene for nematode resistance in sugar beet. Science 1997, 275, 832-834. [CrossRef] [PubMed] 
105. Williamson, V.M.; Kumar, A. Nematode resistance in plants: The battle underground. Trends Genet. 2006, 22, 396-403. [CrossRef] [PubMed]

106. Ernst, K.; Kumar, A.; Kriseleit, D.; Kloos, D.-U.; Phillips, M.S.; Ganal, M.W. The broad-spectrum potato cyst nematode resistance gene (Hero) from tomato is the only member of a large gene family of NBS-LRR genes with an unusual amino acid repeat in the LRR region. Plant J. 2002, 31, 127-136. [CrossRef]

107. Hauge, B.M.; Wang, M.L.; Parsons, J.D.; Parnell, L.D. Nucleic Acid Molecules and Other Molecules Associated with Soybean Cyst Nematode Resistance. U.S. Patents US7154021B2, 26 December 2006.

108. Milligan, S.B.; Bodeau, J.; Yaghoobi, J.; Kaloshian, I.; Zabel, P.; Williamson, V.M. The root knot nematode resistance gene $\mathrm{Mi}$ from tomato is a member of the leucine zipper, nucleotide binding, leucine-rich repeat family of plant genes. Plant Cell 1998, 10, 1307-1319. [CrossRef]

109. Paal, J.; Henselewski, H.; Muth, J.; Meksem, K.; Menéndez, C.M.; Salamini, F.; Ballvora, A.; Gebhardt, C. Molecular cloning of the potato Gro1-4 gene conferring resistance to pathotype Ro1 of the root cyst nematode Globodera rostochiensis, based on a candidate gene approach. Plant J. 2004, 38, 285-297. [CrossRef]

110. Sobczak, M.; Avrova, A.; Jupowicz, J.; Phillips, M.S.; Ernst, K.; Kumar, A. Characterization of susceptibility and resistance responses to potato cyst nematode (Globodera spp.) infection of tomato lines in the absence and presence of the broad-spectrum nematode resistance Hero gene. Mol. Plant-Microbe Interact. 2005, 18, 158-168. [CrossRef]

111. Van Der Vossen, E.A.; Van Der Voort, J.N.R.; Kanyuka, K.; Bendahmane, A.; Sandbrink, H.; Baulcombe, D.C.; Bakker, J.; Stiekema, W.J.; Klein-Lankhorst, R.M. Homologues of a single resistance-gene cluster in potato confer resistance to distinct pathogens: A virus and a nematode. Plant J. 2000, 23, 567-576. [CrossRef]

112. Vos, P.; Simons, G.; Jesse, T.; Wijbrandi, J.; Heinen, L.; Hogers, R.; Frijters, A.; Groenendijk, J.; Diergaarde, P.; Reijans, M. The tomato Mi-1 gene confers resistance to both root-knot nematodes and potato aphids. Nat. Biotechnol. 1998, 16, 1365. [CrossRef] [PubMed]

113. Atkinson, H.J.; Grimwood, S.; Johnston, K.; Green, J. Prototype demonstration of transgenic resistance to the nematode Radopholus similis conferred on banana by a cystatin. Transgenic Res. 2004, 13, 135-142. [CrossRef]

114. Li, Y.; Wang, K.; Lu, Q.; Du, J.; Wang, Z.; Wang, D.; Sun, B.; Li, H. Transgenic Nicotiana benthamiana plants expressing a hairpin RNAi construct of a nematode Rs-cps gene exhibit enhanced resistance to Radopholus similis. Sci. Rep. 2017, 7, 13126. [CrossRef]

115. Fogain, R.; Gowen, S.R. Investigations on possible mechanisms of resistance to nematodes in Musa. Euphytica 1995, 92, 375-381. [CrossRef]

116. Hölscher, D.; Dhakshinamoorthy, S.; Alexandrov, T.; Becker, M.; Bretschneider, T.; Buerkert, A.; Crecelius, A.C.; De Waele, D.; Elsen, A.; Heckel, D.G. Phenalenone-type phytoalexins mediate resistance of banana plants (Musa spp.) to the burrowing nematode Radopholus similis. Proc. Natl. Acad. Sci. USA 2014, 111, 105-110.

117. Vu, T.; Sikora, R.; Hauschild, R. Fusarium oxysporum endophytes induced systemic resistance against Radopholus similis on banana. Nematology 2006, 8, 847-852. [CrossRef]

118. Thompson, J.P.; Brennan, P.S.; Clewett, T.G.; Sheedy, J.G.; Seymour, N.P. Progress in breeding wheat for tolerance and resistance to root-lesion nematode (Pratylenchus thornei). Australas. Plant Pathol. 1999, 28, 45-52. [CrossRef]

119. Sheedy, J.G.; Thompson, J.P. Resistance to the root-lesion nematode Pratylenchus thornei of Iranian landrace wheat. Australas. Plant Pathol. 2009, 38, 478-489. [CrossRef]

120. Thompson, J.P.; Haak, M.I. Resistance to root-lesion nematode (Pratylenchus thornei) in Aegilops tauschii Coss., the D-genome donor to wheat. Aust. J. Agric. Res. 1997, 48, 553-560. [CrossRef]

121. Zwart, R.S.; Thompson, J.P.; Godwin, I.D. Genetic analysis of resistance to root-lesion nematode (Pratylenchus thornei) in wheat. Plant Breed. 2004, 123, 209-212. [CrossRef]

122. Mwaura, P.; Niere, B.; Vidal, S. Resistance and tolerance of potato varieties to potato rot nematode (Ditylenchus destructor) and stem nematode (Ditylenchus dipsaci). Ann. Appl. Biol. 2015, 166, 257-270. [CrossRef]

123. Ristaino, J.B.; Thomas, W. Agriculture, methyl bromide, and the ozone hole: Can we fill the gaps? Plant Dis. 1997, 81, 964-977. [CrossRef] [PubMed]

124. Martin, F.N. Development of alternative strategies for management of soilborne pathogens currently controlled with methyl bromide. Annu. Rev. Phytopathol. 2003, 41, 325-350. [CrossRef] [PubMed]

125. Zasada, I.A.; Halbrendt, J.M.; Kokalis-Burelle, N.; LaMondia, J.; McKenry, M.V.; Noling, J.W. Managing nematodes without methyl bromide. Annu. Rev. Phytopathol. 2010, 48, 311-328. [CrossRef] 
126. Carpenter, J.; Gianessi, L.; Lynch, L. The Economic Impact of the Scheduled Phase-out of Methyl Bromide; National Center for Food and Agricultural Policy: Washington, DC, USA, 2000; 466p.

127. Carpenter, J.; Lynch, L.; Trout, T. Township limits on 1, 3-D will impact adjustment to methyl bromide phase-out. Calif. Agric. 2001, 55, 12-18. [CrossRef]

128. New Rules Governing Use of Fumigant Pesticide 1,3-D. Available online: https://www.cdpr.ca.gov/docs/ pressrls/2016/161006.htm (accessed on 30 September 2019).

129. Sipes, B.; Myers, R. Plant Parasitic Nematodes in Hawaiian Agriculture. In Plant Parasitic Nematodes in Sustainable Agriculture of North America: Vol.1—Canada, Mexico and Western USA; Subbotin, S.A., Chitambar, J.J., Eds.; Sustainability in Plant and Crop Protection; Springer International Publishing: Cham, Switzerland, 2018; pp. 193-209. ISBN 978-3-319-99585-4. [CrossRef]

130. Sipes, B.; Kuehnle, A.; Lichty, J.; Sewake, K.; Hara, A. Anthurium Decline: Options for Controlling Burrowing Nematodes. Plant Dis.June 2004, 26.

131. Zouhar, M.; Douda, O.; Dlouhý, M.; Lišková, J.; Maňasová, M.; Stejskal, V. Using of hydrogen cyanide against Ditylenchus dipsaci nematode present on garlic. Plant Soil Environ. 2016, 62, 184-188. [CrossRef]

132. Zasada, I.A.; Walters, T.W. Effect of application timing of oxamyl in nonbearing raspberry for Pratylenchus penetrans management. J. Nematol. 2016, 48, 177. [CrossRef] [PubMed]

133. Burelle, N. Review of the non-fumigant nematicides oxamyl and fosthiazate. In Proceedings of the International Conference on Methyl Bromide Alternatives and Emissions Reductions, San Diego, CA, USA, 1-3 November 2005; Volume 110, pp. 1-2.

134. Jordaan, E.M.; Loots, G.C.; Jooste, W.J.; De Waele, D. Effects of root-lesion nematodes (Pratylenchus brachyurus Godfrey and P. zeae Graham) and Fusarium moniliforme Sheldon alone or in combination, on maize. Nematologica 1987, 33, 213-219.

135. da Silva, M.P.; Tylka, G.L.; Munkvold, G.P. Seed treatment effects on maize seedlings coinfected with Fusarium spp. and Pratylenchus penetrans. Plant Dis. 2016, 100, 431-437. [CrossRef]

136. Farias, B.V.; Pirzada, T.; Mathew, R.; Sit, T.L.; Opperman, C.; Khan, S.A. Electrospun Polymer Nanofibers as Seed Coatings for Crop Protection. ACS Sustain. Chem. Eng. 2019, 7, 19848-19856. [CrossRef]

137. Barbosa, P.; Lima, A.S.; Vieira, P.; Dias, L.S.; Tinoco, M.T.; Barroso, J.G.; Pedro, L.G.; Figueiredo, A.C.; Mota, M. Nematicidal activity of essential oils and volatiles derived from Portuguese aromatic flora against the pinewood nematode, Bursaphelenchus xylophilus. J. Nematol. 2010, 42, 8. [PubMed] 